\title{
DESIGN OF A SOLAR DRYER FOR SMALL-FARM LEVEL USE AND STUDYING FIG QUALITY
}

\author{
Younés Noutfia ${ }^{1 凶}$, Aouatif Benali², Chakib Alem³, Younes Filali Zegzouti ${ }^{3}$ \\ ${ }^{1}$ Research and Development Unit, Regional Center for Agricultural Research - Errachidia \\ La Marche Verte Av., BP 02, Errachidia Principale 52003, Morocco \\ ${ }^{2}$ Food Technology and Quality Laboratory, Regional Center for Agricultural Research - Rabat \\ Ennasr Av., Rabat 10000, Morocco \\ ${ }^{3}$ Research Team in Biochemistry and Natural Substances, FSTE-UMI \\ BP 509, Boutalamine 52000, Errachidia, Morocco
}

\begin{abstract}
Background. In the mountain areas of south-east Morocco, farmers are engaged in the solar drying of figs using traditional processes. However, this practice leads to losses in quality. This study aims to improve this drying method by designing and studying the performance of a natural convection solar dryer and the quality of fresh and dried figs.

Materials and methods. An indirect solar dryer was designed and its performance was studied. The TSS content, moisture, firmness and morphological parameters of fresh and dried figs were determinated.

Results. The average difference (inside/outside) in the temperature of the dryer is $+8.3^{\circ} \mathrm{C}$. This will allow a decrease in the mean drying duration from 10 days (traditional drying) to 4 days. This duration is significantly correlated with air humidity $\left(R^{2}=0.84\right)$ and temperature $\left(R^{2}=0.63\right)$. The relationship between the degree of dehydration (\%) and time follows a polynomial model with a determination coefficient of 0.98 . Fig-drying yield is $38.7 \%$ and dried figs have a high (TSS) content with $63.7 \%$ and a firmness of $6.03 \mathrm{~kg} / \mathrm{cm}^{2}$. The water content was approximately $25.6 \%$.

Conclusion. The solar dryer with natural convection designed in this study can be an alternative to traditional drying practised by small farmers in the mountainous regions of Errachidia.
\end{abstract}

Keywords: solar, dryer, fresh, dried, figs, quality, mountain area, Morocco

\section{PRACTICAL APPLICATIONS}

The main application of this study is to develop of a new and simple method of solar drying in order to preserve the quality of fruit, vegetable and aromatic plants. Moreover, due to its low price: about $300 \$$ for the prototype proposed in this study this dryer will be very accessible for rural populations, especially small farmers and women.

Finally, the dryer proposed in this work allows good preservation of the environment by the sole use of solar energy: it uses non-polluting equipment

This work was funded by Partnership N01/2010 between INRA and ORMVATF "Research and Development on Different Cultures at Mountain Areas of Action Region of ORMVATF".

『noutfiaa@yahoo.fr; phone +212623063696 
and use of renewable and free energy (sun), produces good-quality dried products compared to traditional solar drying and enables the duration of solar drying to be reduced.

\section{INTRODUCTION}

Sun-drying has largely developed in arid and semiarid areas with optimal climatic conditions: a long dry season with high levels of sunshine, low rainfall and low humidity. Sun-drying permits the shelf life of surplus production that cannot be sold or consumed immediately to be extended. The interest of this mode of conservation is due to its simplicity and very low cost (El Mazhor, 1985).

The fig (Ficus carica L.), one of the most important fruit species in these areas, is highly perishable, even in refrigerated conditions (Hardenburg et al., 1986; Piga et al., 1995), and thus nearly all global production is preserved in a dried form. In the mountain areas of Errachidia (south-east Morocco), the fig is an important fruit and source of income, which is sold both as a fresh and dried product. The majority of farmers are engaged in solar drying of this fruit based on traditional methods (Noutfia, 2012).

The results obtained by traditional drying are qualitatively mediocre, because the products are loaded with sand and dust. They are attacked by animals, insects, micro-organisms and molds (Ait Haddou et al., 2014; Dudez, 2000). Furthermore, there is a risk of aflatoxins developing (Piga et al., 2004). Direct exposure to sunlight has a negative effect on ascorbic acid content and damages the color of fruit (Ali et al., 2016). Quantitative losses are also significant.

In order to improve the traditional method of solar drying, equipment using various energy sources (electricity, fuel, gas, wood fires) has been developed (El Khaloui, 2010). This equipment is expensive to install and operate. They require high technicality for their design, installation, use and maintenance. In addition, investment in this type of equipment is difficult for rural farmers to sustain (Dudez, 2000).

Thus, there is a need to develop a simple method of solar drying in order to preserve the quality of fruit and to provide support for fragile rural populations, especially small farmers and women. This study focuses on designing and studying the performance of an indirect solar dryer prototype that uses natural convection to dry figs. In addition, the quality of dried figs was evaluated.

\section{MATERIAL AND METHODS}

\section{Dryer design and composition}

An indirect solar dryer was designed with low-cost production and affordability in mind. This dryer is composed of 3 main components: (1) a drying chamber, (2) a solar collector, and (3) a dryer support. The dimensions of these components are as follows (in meters):

$$
\begin{aligned}
H \times L \times w & =1.25 \times 0.63 \times 0.61 \\
L \times w & =1.16 \times 0.63 \\
\text { and } H \times L \times w & =(0.65 \times 1.70 \times 0.65)
\end{aligned}
$$

where:

$$
\begin{aligned}
& H \text { - height, } \\
& L \text { - length, } \\
& w \text { - width. }
\end{aligned}
$$

The prototype was constructed using various materials for maximum sealing and heat optimization, as described by (Dadda et al., 2008; Dudez, 2000; Ferradji et al., 2001; ICARO, 1998).

The solar dryer includes:

- a "solar collector", for heating the air

- a "drying chamber" made entirely of slatted wood; on its front face, a door enables the loading and unloading of figs; "racks" for supporting figs to allow them to dry and for air to circulate; "holes" for extracting trapped hot air by a thermosiphon

- a "support system" to facilitate movement of the dryer.

The proposed model is presented in Figure 1. The solar dryer was installed at the Experimental Station of Errachidia (longitude: $4^{\circ} 25^{\prime}$ and latitude: $31^{\circ} 75^{\prime}$ ). It was facing south with a latitude of $32^{\circ}$. This orientation allows better absorption of solar radiation throughout the day (Tadili and Bargach, 2005).

\section{Fig-drying experiments}

Figs (Ficus carica L.) from local cultivars were planted in the Errachidia Experimental station (altitude: $1029 \mathrm{~m}$, longitude: $4^{\circ} 25^{\prime}$, latitude: $31^{\circ} 75^{\prime}$ ) in 2015 . All trees were managed according to integrated cultivation protocols and trained as an open vase with 


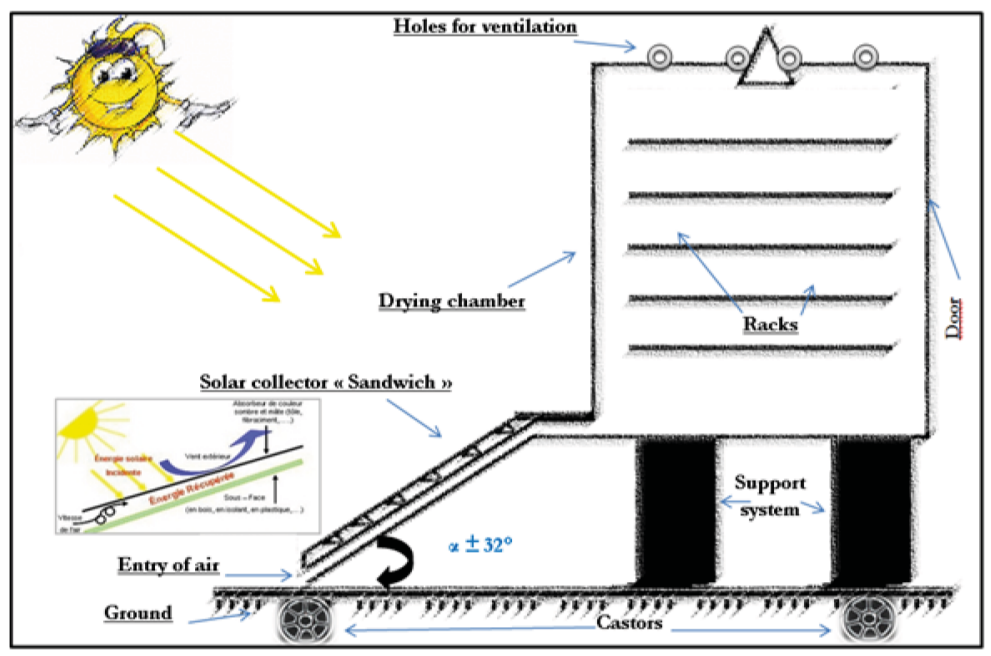

Fig. 1. Schematic representation of the proposed dryer model

$6 \times 4 \mathrm{~m}$ spacing. The fruits were harvested at the end of August at commercial maturity and immediately transported to the laboratory, where only fruits with no or minimal peel defects were selected. The figs were blanched in boiling water $\left(100^{\circ} \mathrm{C}\right)$ for five minutes. Blanching destroys microorganisms, renders the walls of the figs permeable and slows down the degradation of skin color. Seven fig batches of about 1500 grams each were dried. The figs were placed into the dryer and distributed uniformly on a sample tray in a single layer. The process was carried out around the clock but temperature and relative humidity was measured during the day (between 8 am and $8 \mathrm{pm}$ ).

\section{Evaluation of the dryer performances}

Daily temperatures inside (in) and outside (out) the dryer were recorded (every hour) between 8 am and $8 \mathrm{pm}$ over a period of 42 days during August and September 2015 using 2 digital thermometers (ELITECH ST 1A, London-UK). The relative humidity of drying air was also controlled by a hand hygrometer ATE (France). Drying kinetics were determined by measuring the degree of dehydration [\%], which was defined as weight loss recorded every 4 hours (during the day). It was determined by weighing the fig fruits on a precision scale (Mettler Toledo-USA). Drying is stopped if no liquid escapes from the fig when it is pressed between the thumb and forefinger (Bahlouli et al., 2008). Subsequently, figs were analyzed for their physicochemical quality before and after the drying process.

\section{Quality analysis}

The analysis focused on the following:

- Water content: was determinated according to the OECD-2005 standards

- Total soluble solids (TSS): This component was measured with juice obtained from diluting 100 grams of figs into $500 \mathrm{ml}$ of distillated water. A hand refractometer (Model DR-A1; Atago, Japan) was used for measuring this parameter (TSS/ Brix). Results were expressed as apercentage of total soluble solids (TSS, \%) in juice at $25^{\circ} \mathrm{C}$

- Firmness: Ten fruits per batch were used for this measurement. Two readings on the digital screen of a hand pentrometer PCE-PTR 200 (France) were taken on opposite checks of figs. The firmness of all fig samples was evaluated with a cylindrical puncture probe with the diameter of $8 \mathrm{~mm}$ at room temperature (about $25^{\circ} \mathrm{C}$ )

- Dimensions: The length and diameter of 10 fruit per batch were determined using a vernier caliper device.

\section{Statistical analysis of results}

Statistical analysis was carried out using IBM SPSS Statistics-19 software and consisted of computing the mean, minimum, maximum and standard error of 


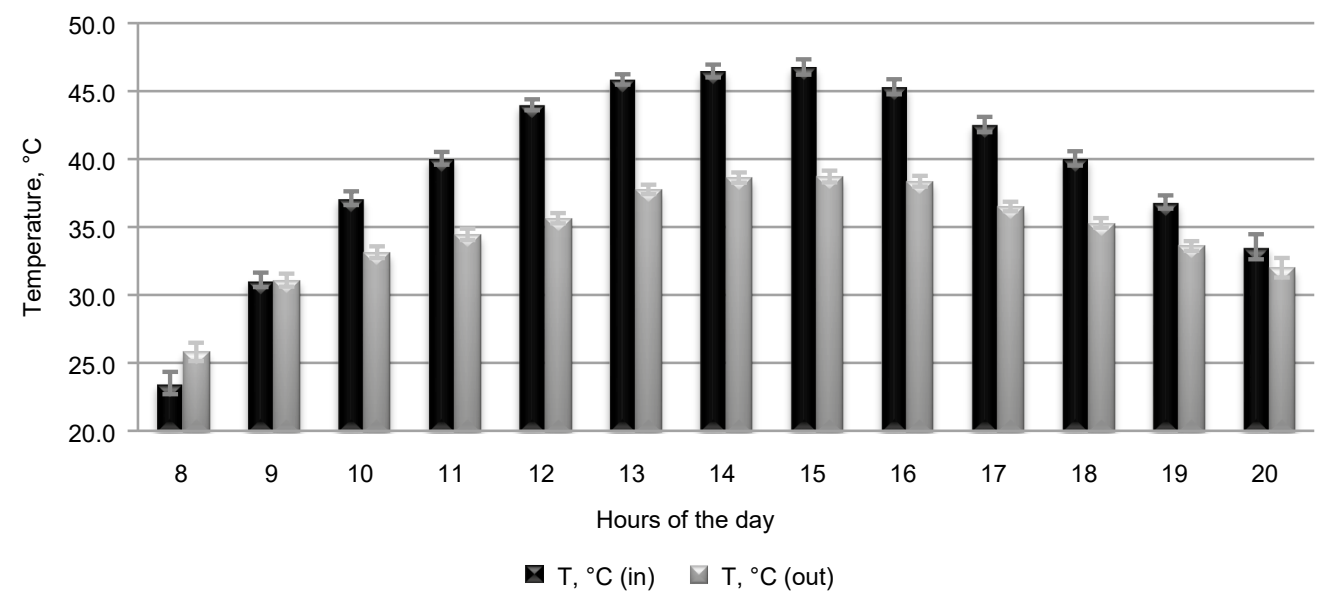

Fig. 2. Evolution of the temperature inside (in) and outside (out) the dryer

the mean (SEM) of each parameter analyzed. In addition, a correlation model between fig loss weight and time of drying was produced.

\section{RESULTS AND DISCUSSION}

\section{Evaluation of the dryer performances}

During this experimental work, the test conditions can be summarized as follows: relative humidity varies between $20.9 \%$ and $29.9 \%$. The ambient temperature oscillates between $25.8^{\circ} \mathrm{C}$ and $38.7^{\circ} \mathrm{C}$. The mean evolution of the temperature inside (in) and outside (out) the dryer is reported in Figure 2.

The daily mean temperature inside the dryer was significantly greater than the mean temperature outside the dryer until $10 \mathrm{am}$ (Fig. 2). In-out temperature mean differences increased over time and reached $8.3^{\circ} \mathrm{C}$, on average, between $12 \mathrm{~h}$ and $15 \mathrm{~h}$. The maximum drying temperature was $51{ }^{\circ} \mathrm{C}$, yielding temperature differences that exceeded $12^{\circ} \mathrm{C}$ in some cases. These findings are consistent with a previous study (Bochu, 2003; Pangavhane et al., 2002), where the drying air temperature increased up to $50-55^{\circ} \mathrm{C}$ with an in-out temperature difference of $8.1^{\circ} \mathrm{C}$.

For the same model of dryer, Sari Farah et al. (2015) reported that during hours of sunshine, the maximum temperature within the drying chamber varied from $40^{\circ} \mathrm{C}$ to $54^{\circ} \mathrm{C}$, with an in-out temperature difference of $9-12^{\circ} \mathrm{C}$.

\section{Fig-drying kinetics}

In our experimental conditions, which can be defined as mild compared with common industrial practice, the main parameters related to sun-drying are: temperature $\left(40.1^{\circ} \mathrm{C} \pm 0.31\right)$ and humidity $(26.3 \% \pm 0.31)$.

Drying kinetics have been studied to further evaluate the performances of the dryer. Figure 3 shows the rate of desiccation of figs for different batches.

Polynomial and linear models were fitted to correlate the relationship between fig loss weight and time $\left(R^{2}=0.86\right.$ for the polynomial model and $R^{2}=0.68$ for the linear one). Half of the water content was lost during the first 50 hours of the drying process (Fig. 3). The drying time varied from $75 \mathrm{~h}$ to $151 \mathrm{~h}$ among batches with a drying average time of $102 \mathrm{~h}$ (about 4 days). This duration is much smaller than those shown under farmer conditions (7-15 days) (Noutfia, 2012), or when a direct solar dryer (219 hours of drying) at an average temperature of $45^{\circ} \mathrm{C}$ was used (Benkhelfellah et al., 2005). These findings demonstrated that the solar dryer used in this study reduced the drying time significantly. On the other hand, differences shown in drying times may be due to variations in climatic conditions and fig characteristics, such as skin hardness, water and sugar content (Piga et al., 2004) and firmness.

Correlation analyses were conducted to evaluate the relationships between drying time and distinct fruit characteristics (water content and skin firmness) and 
Noutfia, Y., Benali, A., Alem, C., Filali Zegzouti, Y. (2018). Design of a solar dryer for small-farm level use and studying fig quality. Acta Sci. Pol. Technol. Aliment., 17(4), 359-365. http://dx.doi.org/10.17306/J.AFS.2018.0599

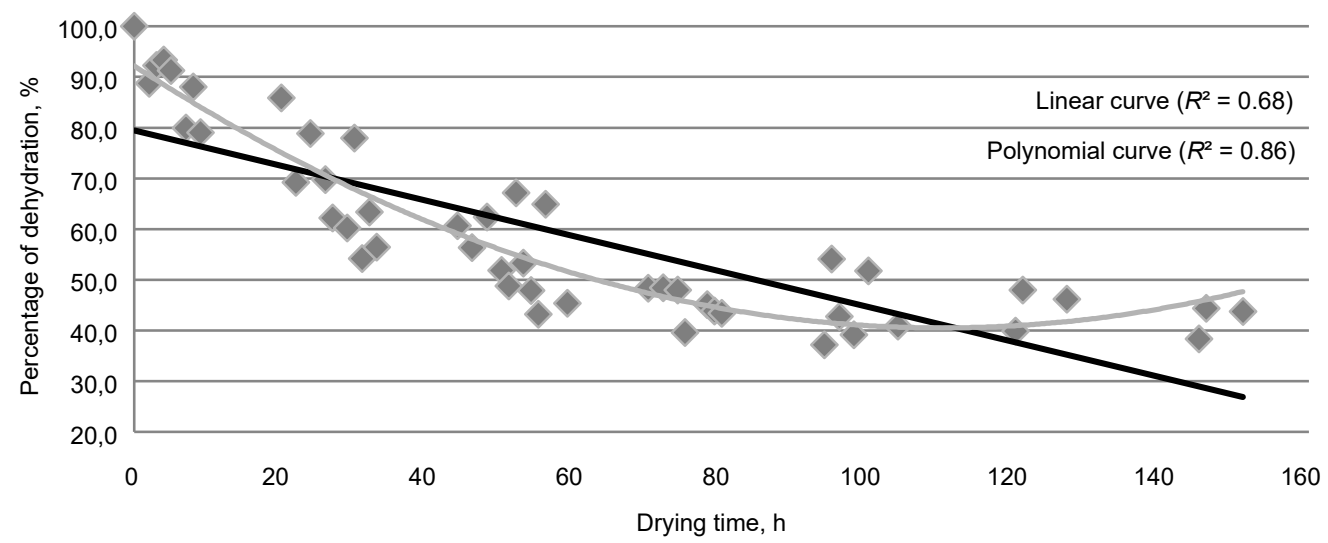

Fig. 3. Kinetics of drying figs

other drying condition factors (humidity and temperature). These correlations are reported in Table 1.

Humidity and temperature had the strongest correlation with drying time. The water content of figs explained only $48 \%$ of the variation in drying time. However, exchange heat surface and firmness were weak correlated. Thus, humidity and temperature are the best predictors of fig-drying duration using a natural convection solar dryer. These findings are in line with those of a previous study (Khama et al., 2009)

Table 1. Correlation between some physicochemical parameters and drying time

\begin{tabular}{lc}
\hline \multicolumn{1}{c}{ Parameters } & Linear correlation $\left(R^{2}\right) /$ dry time \\
\hline Relative humidity & 0.84 \\
Temperature & 0.63 \\
Water content & 0.48 \\
Firmness & 0.04 \\
\hline
\end{tabular}

demonstrating that fig-drying time is significantly affected by temperature and air speed. Nonetheless, other factors, such as cultivar effect, can also impact significantly on fig-drying time (Ait Haddou et al., 2014).

\section{Qualitative parameters of figs}

Fresh figs. Qualitative characteristics of fresh figs (prior to drying) are shown in Table 2. The fresh figs in this study had a smaller average weight $(24 \mathrm{~g})$ than those observed for figs from northern Morocco (30-65 g) (Ouaouich and Chimi, 2005) and for "Brown Turkey and Sierra cultivars" (44.5-59.7 g; Hong et al., 2016). Fresh figs from the area of the study had a higher sugar content $(27.8 \%)$ than that of other types of figs from either Morocco or other countries. A range of $13.5 \%$ to $26 \%$ was reported by Ait Haddou et al. (2014), Mehraj et al. (2013) and Siddiq et al. (2012). For water content, Abul-Fadl et al. (2015), EL-Gendy (2014) and Piga et al. (2004) mentioned a percentage of $83.4 \%, 75 \%$ and $71.5 \%$, respectively. Those findings are smaller than the moisture content obtained in this study.

Table 2. Qualitative parameters of fresh figs

\begin{tabular}{lcccccc}
\hline & $\begin{array}{c}\text { Number of figs } \\
/ \mathrm{kg}\end{array}$ & $\begin{array}{c}\text { Water content } \\
\%\end{array}$ & $\begin{array}{c}\text { TSS } \\
\%\end{array}$ & $\begin{array}{c}\text { Firmness } \\
\mathrm{kg} / \mathrm{cm}^{2}\end{array}$ & $\begin{array}{c}\text { Length } \\
\mathrm{cm}\end{array}$ & $\begin{array}{c}\text { Diameter } \\
\mathrm{cm}\end{array}$ \\
\hline Mean & 41.3 & 70.9 & 27.8 & 1.82 & 2.76 & 3.37 \\
SEM & 2.37 & 1.08 & 1.00 & 0.55 & 0.10 & 0.07 \\
Min & 33 & 66.2 & 24.0 & 0.77 & 2.52 & 3.10 \\
Max & 51 & 73.3 & 32.5 & 4.39 & 3.16 & 3.62 \\
\hline
\end{tabular}


Noutfia, Y., Benali, A., Alem, C., Filali Zegzouti, Y. (2018). Design of a solar dryer for small-farm level use and studying fig quality. Acta Sci. Pol. Technol. Aliment., 17(4), 359-365. http://dx.doi.org/10.17306/J.AFS.2018.0599

Table 3. Qualitative parameters of dried figs

\begin{tabular}{lccccccc}
\hline & $\begin{array}{c}\text { Yield } \\
\%\end{array}$ & $\begin{array}{c}\text { Number of figs } \\
/ \mathrm{kg}\end{array}$ & $\begin{array}{c}\text { Water content } \\
\%\end{array}$ & $\begin{array}{c}\text { TSS } \\
\%\end{array}$ & $\begin{array}{c}\text { Firmness } \\
\mathrm{kg} / \mathrm{cm}^{2}\end{array}$ & $\begin{array}{c}\text { Length } \\
\mathrm{cm}\end{array}$ & $\begin{array}{c}\text { Diameter } \\
\mathrm{cm}\end{array}$ \\
\hline Mean & 38.7 & 104.3 & 25.6 & 63.7 & 6.03 & 1.34 & 2.95 \\
SEM & 1.38 & 5.90 & 1.55 & 3.26 & 0.46 & 0.06 & 0.12 \\
Min & 33.9 & 85 & 19.5 & 55.0 & 3.91 & 1.15 & 2.61 \\
Max & 43.8 & 131 & 31.1 & 78.0 & 7.19 & 1.49 & 3.29 \\
\hline
\end{tabular}

Dried figs. The qualitative parameters of figs following drying in the indirect solar dryer with natural convection are summarized in Table 3. According to the CEE-ONU DDP 14 Standard (related to the marketing and commercial quality control of dried figs), the dried figs obtained in this study can be classified as 1st category-calibre10. The water content of dried figs is greater than that recorded on dried figs of several Moroccan varieties, and varies between $19 \%$ and $24.3 \%$ (Ait Haddou et al., 2014). Naikwadi et al. (2010) also found water content of $19 \%$. These differences may be attributed to some pre-treatment like blanching and sulphitation (Gawade and Waskar, 2003). However, our value is compared to the recommendations of the United Nations Economic Commission for Europe (UNECE), which suggests a maximal moisture content of 26\% (UNECE, 2004). Similarly, TSS was notably greater compared to the findings from other studies (Bolin and King, 1980; Hiregoudar, 2010; Naikwadi et al., 2010). In these studies, the rate of total solid sugars did not exceed $58 \%, 36 \%$ and $55 \%$, respectively.

\section{CONCLUSION}

In conclusion, the solar dryer with natural convection designed in this study can be an alternative to traditional drying practised by small farmers in the mountainous regions of Errachidia.

This dryer reduced the drying duration from 10 days to 4 days on average and preserved the nutritional and physical qualities of dried figs. All drying process take place in the shade (in a drying chamber) with a temperature average difference of $8.3^{\circ} \mathrm{C}$ between the ambient and drying air. Drying-air temperature and relative humidity are accurate predictors of drying duration. Further refinement of the performance of the dryer (i.e. by a forced convection for better air circulation inside the drying chamber) may improve post-drying fig quality.

\section{ACKNOWLEDGEMENT}

The authors would like to thank Dr. A. Essarioui for his assistance in producing this paper.

\section{REFERENCES}

Abul-Fadl, M. M., Ghanem, T. H., EL-Badry, N., Nasr, A. (2015). Effect of some different drying methods on quality criteria of dried fig fruits. Curr. Sci. Int., 4(4), 548-566.

Ait Haddou, L., Blenzar, A., Messaoudi, Z., Van Damme, P., Boutkhil, S., Boukdame, A. (2014). Effet du cultivar, du prétraitement et de la technique de séchage sur quelques paramètres physico-chimiques des figues séchées de sept cultivars locaux du figuier au Maroc. Eur. J. Sci. Res., 121(4), 336-346.

Ali, M. A., Yusof, Y. A., Chin, N. L., Ibrahim, M. N. (2016). Effect of different drying treatments on colour quality and ascorbic acid concentration of guava fruit. Int. Food Res. J., 23(Suppl), 155-161.

Bahlouli, F., Tiaiba, A., Slamani, A. (2008). Etude des différentes méthodes de séchage d'abricot, point sur les méthodes de séchage traditionnelles dans la région du Hodna, wilaya de M'Sila. Rev. Ener. Renouv. SMSTS'08 Alger, 61-66.

Benkhelfellah, R., El Mokretar, S., Miri, R., Belhamel, M. (2005). Séchoirs solaires. Etude comparative de la cinétique de séchage des produits agroalimentaires dans des modèles de type direct et indirect. 12èmes J. Int. Thermiq., Tanger, Maroc 15-17 Novembre 2005, 259-262.

Bochu, J. L. (2003). Energies et agriculture: de la maîtrise de l'énergie aux énergies renouvelables. Dijon: Educagri. 
Noutfia, Y., Benali, A., Alem, C., Filali Zegzouti, Y. (2018). Design of a solar dryer for small-farm level use and studying fig quality. Acta Sci. Pol. Technol. Aliment., 17(4), 359-365. http://dx.doi.org/10.17306/J.AFS.2018.0599

Bolin, H. R., King, A. D. (1980). Fig. In: S. Nagy, P. E. Shaw (Eds.), Tropical and subtropical fruits - composition, properties, and uses (pp. 492-505). Westport CT: AVI Publ.

Dadda, B., Kherrour, S., Serir, L. (2008). Réalisation d'un séchoir solaire indirect. Rev. Energ. Renouv. SMSTS'08, $127-134$

Dudez, P. (2000). Guide pratique: Le séchage solaire à petite échelle des fruits et légumes. Expériences et procédés. Paris: Editions du GRET.

EL-Gendy, M. A. (2014). Evaluation of quality attributes of dehydrated figs prepared by osmotic-drying process. Egypt. J. Agric. Res., 92(1), 337-347.

El Khaloui, M. (2010). Valorisation de la figue au Maroc. Bulletin mensuel d'information et de liaison du PNTTA. Transf. Technol. Agric., 186, 1-4.

El Mazhor, A. (2014). Séchage solaire au Maroc. Retrieved February 5 from: http://www.fao.org/docrep/x5018e/ x5018E0J.HTM

Ferradji, A., Malek, A., Bedoud, M., Baziz, R., Aoua, S. A. (2001). Séchoir solaire à convection forcée pour le séchage des fruits en Algérie. Rev. Energ. Ren., 4, 49-59.

Gawade, M. H., Waskar, D. P. (2003). Studies on processing and storage of fig fruits. J. Maharashtra Agric. Univ., 28, 148-150.

Hardenburg, R. E., Watada, A. E., Wang, C. Y. (1986). The commercial storage of fruits, vegetables and nursery stocks. Agriculture Handbook 66. Washington: USDA.

Hiregoudar, S., Nidoni, U., Meda, V., Gadade, S., Basavaraj, V. P. (2010). A study of different drying methods for fig (Ficus carica Linn) fruit. MBSK 10-505, ASABE/CSBE North Central Intersectional Meeting. http:// dx.doi.org/10.13031/2013.36290

Hong, G. C., Crisosto, C., Cantwell, M. I. (2016). Quality and physiology of two cultivars of fresh-cut figs in relation to ripeness, storage temperature and controlled atmosphere. Acta Hortic., 1141, 213-219.

ICARO (1998). Séchoir solaire à ventilation forcée pour aliments. Manuel pour la construction et l'utilisation. Programme régional pour la sûreté alimentaire dans les Pays en voie de développement. Italie: Université de Torino.

Khama, R., Belhamri, A., Bennamoun, L. (2009). Analyse des transferts couplés de chaleur et de masse pendant le séchage des figues. Rev. Algér. Physiq., 3, 50-54.

Mehraj, H., Sikder, R. K., Haider, M. N., Hussain, M. S., Jamal Uddin, A. F. M. (2013). Fig (Ficus carica L.): a new fruit crop in Bangladesh. Int. J. Busin. Soc. Sci. Res. $1(1), 1-05$.
Naikwadi, P. M., Chavan, U. D., Pawar, V. D., Amarowicz, R. (2010). Studies on dehydration of figs using different sugar syrup treatments. J. Food Sci. Technol., 47(4), $442-445$.

Noutfia, Y. (2012). Séchage des figues. Annual report of Convention $\mathrm{N}^{\circ} 1 / 2010$ INRA-ORMVATF relative à la réalisation des travaux de recherche-développement sur différentes cultures au niveau des zones montagneuses de la zone d'action de l'ORMVA-TF.

OECD (2015). Organisation de coopération et de développement économiques. Orientation pour la réalisation des tests objectifs visant à déterminer la qualité interne des fruits et légumes frais et secs et séchés. Normalisation Internationale des fruits et légumes. Retrieved July 7, 2015, from: https://www.oecd.org/fr/tad/ code/36295388.pdf

Ouaouich, A., Chimi, H. (2015). Guide du sécheur de figues. US/MOR/04/A48. Organisation des Nations Unies pour le développement industriel. Retrieved June 22, 2015, from: http://www.unido.org/.../41755_Guide SecheurFigues_3a_withoutFrontAndBackCover.pdf

Pangavhane, D. R., Sawhney, R. I., Sarsavadia, P. N. (2002). Design, development and performance testing of new natural convection solar dryer. Energy, 27, 579-590.

Piga, A., D’Aquino, S., Agabbio, M., Papoff, C. (1995). Influenza del confezionamento con film plastici sulla conservazione del fico. Italus Hortus, 2, 3-7.

Piga, A., Pinna, I., Ozer, K. B., Agabbio, M., Aksoy, U. (2004). Hot air dehydration of figs (Ficus carica L.): Drying kinetics and quality loss. Int. J. Food Sci. Technol., 39, 793-799.

Sari Farah, D., Himsar, A., Farel, H. N., Hideki, K. (2015). Study on effectiveness of continuous solar dryer integrated with desiccant thermal storage for drying cocoa beans. Case Stud. Thermal Eng., 5, 32-40.

Siddiq, M., Jasim, A., Lobo, M. G., Ozadali, F. (2012). Tropical and subtropical fruits: Postharvest, physiology, processing and packaging. London: Wiley-Blackwell.

Tadili, R., Bargach, M. N. (2005). Une méthode d'estimation $\mathrm{du}$ rayonnement solaire global reçu par une surface inclinée - Application aux sites Marocains. La météorologie, 50, 46-50.

UNECE (2004). United Nations Economic Commission for Europe Standard DDP-01 concerning the marketing and commercial quality control of dried figs. New York-Geneva: United Nations. 